\title{
Design and Testing of the Novel Split Sleeve for Branch Connection Repairs Based on Inter- nal Pressure
}

Marek Patek, Augustín Sládek, Miloš Mičian

University of Žilina, Faculty of Mechanical Engineering, Department of Technological Engineering, Univerzitná 8215/1, 01026 Žilina, Slovakia. E-mail: marek.patek@fstroj.uniza.sk, augustin.sladek@fstroj.uniza.sk, milos.mician@fstroj.uniza.sk

Presented article deals with designing of the novel technology for repairing of the defects in branch connections of the gas pipelines. Until now, defects of the branch connections could be repaired mainly by replacing of the damaged area, especially those allied with gas leakage. The most important requirement of new type of repairing technology is maximal allowable operational pressure, which has to be the same as for repaired pipeline. Dimensions of the split sleeve should be thus designed according to required pressure value. In the case of split sleeve for branch connections, dimensions were determined by the static analysis in ANSYS software. Designed sleeve was after manufacturing process subjected to pressure testing by standardised test to confirm requirements of the standards. Pressure test to destruction was performed in order to determine the weakest place of construction. Proposed repairing solution might lead to reducing of the costs for performing of the branch connections repairs.

Keywords: Pipeline repair, Branch connection defects, Finite element analysis, Internal Pressure

\section{Acknowledgement}

Research has been supported by Scientific Grant Agency of Ministry of Education of the Slovak Republic, grant KEGA 034ŽU-4/2015. Authors acknowledge the grant agency for support.

\section{References}

[1] EGIG. (2015). Gas Pipeline Incidents. 9th Report of the European Gas Pipeline Incident Data Group (period 1970 - 2013), pp. 61. European Gas pipeline Incident data Group.

[2] GAJDOŠ, L. (2000). Spolehlivost plynovodnich potrubí, pp. 217. ČVUT, Praha, Czech Republic. (in Czech)

[3] BATISSE R. (2007). Review of gas transmission pipeline repair methods. In: Safety, Reliability and Risks Associated with Water, Oil and Gas Pipelines, pp. 335-348. Springer, Dordrecht.

[4] MIČIAN M., PATEK M., SLÁDEK, A. (2014). Concept of repairing branch pipes on high-pressure pipelines by using split sleeve. In: Manufacturing Technology, Vol. 14, No. 1, pp. 60-66.

[5] ŽMINDÁK, M., MEŠKO, J., PELAGIĆ, Z., ZRAK, A. (2014). Finite element analysis of crack growth in pipelines. In: Manufacturing Technology, Vol. 14, No. 1, pp. 116-122.

[6] BEER F.P. et al. (2011). Statics and Mechanics of Materials, pp. 714. McGraw-Hill, New York.

[7] ZRAK, A., KOŇÁR, R., JANKEJECH, P. (2015). Influence of chemical composition in steel on laser cutting stability. In: Manufacturing Technology, Vol. 15, No. 4, pp. 748-752.

[8] MEŠKO J., FABIAN P., HOPKO A., KOŇÁR R. (2011). Shape of heat source in simulation program SYSWELD using different types of gases and welding methods. In: Strojírenská technologie, Vol. 16, No. 5, pp. 6-11.

[9] EN 13480-3 Metallic industrial piping. Part 3: Design and calculations, 2012.

[10]EN 12327 Gas infrastructure. Pressure testing, commissioning and decommissioning procedures. Functional requirements, 2012.

[11]TPP 70211 Repairs of high-pressure steel pipelines with maximal allowable operational pressure 40 bar including, 2011. (in Slovak) 